Jurnal Riset Agama

Volume 1, Nomor 3 (Desember 2021): 238-250

DOI: $10.15575 /$ jra.v1i3.15255

https://journal.uinsgd.ac.id/index.php/jra

\title{
Praktek Islam di Era Media Global: Konvergensi Media Sosial sebagai Sumber Ilmu Pengetahuan Agama Islam
}

\author{
Tri Budi Prastyo', Risda Alfi Fat Hanna ${ }^{2}$, Uun Yusufa ${ }^{3}$, Hidayatul Fikra ${ }^{4}$ \\ 1Jurusan Ilmu Al-Qur'an dan Tafsir, Fakultas Ushuluddin \\ UIN K. H. Ahmad Siddiq Jember, Indonesia \\ 2Jurusan Ilmu Hadis, Fakultas Ushuluddin, \\ UIN Sunan Kalijaga Yogyakarta, Indonesia \\ 3 Jurusan Ilmu Al-Qur'an dan Tafsir, Fakultas Ushuluddin \\ UIN K. H. Ahmad Siddiq Jember, Indonesia \\ 4 Jurusan Tasawuf Psikoterapi, Fakultas Ushuluddin, UIN Sunan Gunung \\ Djati Bandung \\ telobudi3@gmail.com, hanna.alfi24@gmail.com, uunyusufa@gmail.com, \\ fikraarza2903@gmail.com
}

\begin{abstract}
Social media in this digital era has become a source of concentration in information. Not a few uses of social media as a source of knowledge in religious values (Islam). This study aims to discuss the practice of Islam in the global media era of social media convergence as a source of Islamic religious knowledge. The research uses a qualitative approach through descriptiveanalytical methods. The results and discussion of this study indicate that the facts that we can see today, there are a lot of misleading, gossiping and immoral actions that originate from various content available on social media, of course, it becomes homework for all, especially parents, teachers and preachers so that they can help. educate the younger generation so that they become wiser and smarter in using social media. This study concludes that in a religious context, the convergence of social media as a source of knowledge has both positive and negative impacts. This study recommends all social media users to continue to adopt sciences whose sources of references and learning narrations are clear, especially on religious issues (Islam).
\end{abstract}

Keywords: Convergence; Knowledge; Media; Religion; Social.

\begin{abstract}
Abstrak
Media sosial di era digital ini menjadi sumber pemusatan dalam informasi. Tidak sedikit yang menggunakan media sosial sebagai sumber ilmu pengetahuan khsususnya dalam ilmu
\end{abstract}


Jurnal Riset Agama, Volume 1, Nomor 3 (Desember 2021): 238-250

Tri Budi Prastyo, Risda Alfi Fat Hanna, Uun Yusufa, Hidayatul Fikra/Praktek Islam di Era Media Global: Konvergensi Media Sosial sebagai Sumber Ilmu Pengetahuan Agama Islam

agama (Islam). Penelitian ini bertujuan untuk membahas praktek Islam di era media global konvergensi media sosial sebagai ilmu pengetahuan Islam. Penelitian menggunakan pendekatan kualitatif melalui metode deskriptif-analitis. Hasil dan pembahasan penelitian ini menunjukkan bahwa fakta yang dapat kita lihat saat ini, banyak sekali tindakan menyesatkan, menggunjing dan asusila yang berawal dari berbagai konten yang tersedia di media sosial tentunya menjadi pekerjaan rumah untuk semuanya terutama orangtua, pengajar dan para pendakwah agar dapat membantu mengedukasi generasi muda sehingga menjadi lebih bijak dan cerdas dalam menggunakan media sosial. Penelitian ini menyimpulkan dalam konteks keagamaan, konvergensi media sosial sebagai sumber ilmu pengetahuan ini menimbulkan dampak positif dan negatif. Penelitian ini merekomendasaikan kepada semua pengguna media sosial untuk tetap terus mengadopsi ilmu-ilmu yang sumber referensi dan periwayatan bergurunya jelas terkhusus permasalahan agama (Islam).

Kata Kunci: Agama; Konvergensi; Media; Pengetahuan; Sosial.

\section{Pendahuluan}

Pada zaman era digital memang sulit dikatakan bahwa manusia tidak mengakses media sosial, sehingga internet berpengaruh besar terhadap meningkatnya intoleransi pada generasi milenial atau generasi Z. Di era milenial saat ini, mengajar ilmu pengetahuan tidak lagi menjadi otoritas seorang pendidik. Masyarakat tidak hanya mengandalkan pendidik sebagai sumber ilmu pengetahuan, melainkan juga memanfaatkan media sosial untuk mengetahui berbagai macam persoalan seperti persoalan agama, ilmu pengetahuan, dan lain sebagainya (Azmi, 2019).

Lain halnya dengan peran ulama zaman dahulu, ketika para ulama mempengaruhi kehidupan masyarakat dengan sikap rela berkorban dalam mencari ilmu pengetahuan yang nantinya dapat dijadikan pedoman dalam menjalankan kehidupan manusia. Pergeseran yang luar biasa tersebut tidak bisa dihindari dan diputar ulang seperti era agraris. Ulama dan pemerintah sekalipun tidak bisa merubah kekuatan tersebut (Rahman \& Nuryana, 2020).

Generasi milenial saat ini membutuhkan informasi-informasi yang seharusnya mampu memberikan pesan positif bagi mereka. Hal ini membuat para pengguna media sosial gencar untuk mencari sumber informasi yang kredibel untuk kebutuhan mereka khususnya dalam kebutuhan religi. Dewasa ini, realita "anak muda zaman now" hadir dengan 
Jurnal Riset Agama, Volume 1, Nomor 3 (Desember 2021): 238-250

Tri Budi Prastyo, Risda Alfi Fat Hanna, Uun Yusufa, Hidayatul Fikra/Praktek Islam di Era Media Global: Konvergensi Media Sosial sebagai Sumber Ilmu Pengetahuan Agama Islam

berbagai macam gaya hidup dan eksistensinya di media sosial (Fatoni \& Nafisah Rais, 2018).

Permasalahan utama penelitian ini adalah terdapat praktek Islam di era media global dan konvergensi media sosial sebagai sumber ilmu pengetahuan agama Islam. Rumusan masalah penelitian ini ialah bagaimana problem konvergensi media sosial sebagai sumber ilmu pengetahuan agama Islam. Tujuan penelitian ini untuk membahas konvergensi media sosial sebagai sumber ilmu pengetahuan agama Islam. Hasil penelitian ini diharapkan memberikan implikasi manfaat, baik teoritis maupun praktis. Secara teoritis, penelitian ini diharapkan dapat memberikan sumbangsih untuk pengayaan khazanah ilmu pengetahuan Islam. Secara praktis, penelitian ini diharapkan menjadi rujukan dalam penerapan konvergensi media sosial sebagai sumber ilmu pengetahuan agama Islam.

Sebagai langkah awal penelitian, memetakan kerangka berpikir sangat penting untuk dilakukan agar mengetahui bagaimana alur logis berjalannya penelitian. Teknologi sebagai artefak merupakan ciri imperatif perkembangan masyarakat yang terus berkembang. Media sosial merupakan sarana efektif yang mampu menjangkau massa dalam jumlah besar dan luas (universality of reach) dan dianggap mempunyai keunggulan yang dapat mempengaruhi pikiran manusia sehingga gaya hidup dapat berubah (Azmi, 2019). Artikel ini mencoba memaparkan kasus fenomena konvergensi media yang memaksa media konvensional melebarkan sayap masuk ke dalam jaringan internet (daring) dan dampak digitalisasi kebebasan demokrasi dalam media massa tersebut dalam kehidupan ekonomi, politik, sosial, budaya dan agama di masyarakat (Gemiharto, 2015).

Konvergensi media merupakan penggabungan atau pengintegrasian media-media yang ada untuk digunakan dan diarahkan ke dalam satu titik tujuan. Istilah konvergensi mulai banyak digunakan sejak tahun 1990-an (Asyir \& Nurbaya, 2019). Di Indonesia, masing-masing media komunikasi tersebut memiliki perjalanan sejarahnya masing-masing. Seiring dengan sejarah perkembangan teknologi komunikasi yang kini memasuki era digital, berbagai media sosial di Indonesia juga mulai memanfaatkan kehadiran internet sebagai media komunikasi untuk menyampaikan jenisjenis informasi dan jenis-jenis berita kepada khalayak yang jauh lebih luas. Selain portal berita, berbagai platform media sosial pun turut dimanfaatkan oleh pemilik media dan jurnalis guna menyampaikan pesan-pesan kepada khalayak. Dengan kemajuan teknologi komunikasi yang demikian hebat, masing-masing anggota masyarakat dunia dapat bekerja sama, bersaing dan saling mempengaruhi dengan bebas. Sekat-sekat geografis dan jarak yang berjauhan tidak lagi menjadi hambatan (Haramain, 2017). Dengan demikian, praktek pendidikan Islam di Era Media Global dengan 
Jurnal Riset Agama, Volume 1, Nomor 3 (Desember 2021): 238-250

Tri Budi Prastyo, Risda Alfi Fat Hanna, Uun Yusufa, Hidayatul Fikra/Praktek Islam di Era Media Global: Konvergensi Media Sosial sebagai Sumber Ilmu Pengetahuan Agama Islam

Kemunculan teknologi 4G-LTE telah membuka kesempatan luas bagi munculnya media sosial baru di Indonesia dan memberikan tantangan untuk melakukan konvergensi media yang telah ada sebagai sumber ilmu pengetahuan agama Islam yang baik.

Penelitian terdahulu telah dilakukan oleh kalangan ahli antara lain Sufyati (2019), “Konvergensi Media dalam Religiusitas Masyarakat," Sosiologi Reflektif. Penelitian ini merupakan penelitian deskriptif kualitiatif dengan menggunakan studi literatur dan data empiris. Ada 4 (empat) aspek yang mempengaruhi pergeseran perilaku religiusitas masyarakat sebagai akibat konvergensi media massa tersebut, mulai dari aspek kehidupan ekonomi, sosial, budaya dan politik. Hasil penelitian menunjukkan bahwa pergeseran media konvensional ke media daring memiliki dampak positif bagi yang memanfaatkan dengan baik, sebaliknya berdampak negatif jika memanfaatkannya secara sia-sia (Sufyati, 2019).

Hatta, M. (2018), "Media Sosial sebagai Sumber Keberagamaan Alternatif Remaja dalam Fenomena Cyber Religion," Jurnal Kajian Dakwah Dan Kemasyarakatan. Penelitian ini bertujuan untuk membuktikan adanya fenomena cyberreligion pada siswa SMA Negeri 6 Depok, Jawa Barat. Ada dua pendekatan analisis yang penulis gunakan pada penelitian ini. Pertama adalah tradisi pemikiran fenomenologis Alferd Schutz terkait aktifitas cyber religion sebagai sebuah fenomena sosial. Kedua, Teori Ketergantungan Media Sandra Ball-Rokeach dan Melvin L. DeFluer (1976) dalam mengungkap aspek ketergantungan siswa pada media sosial dan dampak yang ditimbulkannya. Penelitian ini menggunakan Mixed Methods Research, yakni sebuah metode penelitian gabungan kuantitatif dan kualitatif yang digunakan secara bersama-sama dalam suatu kegiatan penelitian untuk mendapatkan data yang lebih komprehensif, valid, reliabel dan objektif. Beberapa temuan menarik dari penelitian ini mengungkap adanya ketergantungan siswa dalam penggunaan smartphone. Dalam satu hari, siswa minimal menghabiskan waktu 4 jam lebih untuk berselancar di media sosial. Umumnya, siswa menyukai tausiyah dari para ustad atau ulama yang dikaguminya. Antusiasme siswa belajar agama dari para ustad pilihannya di media sosial ini, terkadang juga dilandasi oleh kekaguman yang berlebihan dan bahkan cenderung pada kultus individu (Hatta, 2018).

Priyanto, A. (2020), “Pendidikan Islam dalam Era Revolusi Industri 4.0" dalam J-PAI: Jurnal Pendidikan Agama Islam. Penelitian ini bertujuan mengetahui permasalahan pendidikan Islam yang sedang terjadi dan bagaimana tantangan pendidikan Islam ke depan. Kemudian, bagaimana solusi bagi dunia pendidikan Islam agar mampu bersaing bahkan menjadi acuan dalam pelaksanaan pendidikan di Indonesia. Metode penelitian ini menggunakan studi literatur dengan mengumpulkan data dari dokumentasi menggunakan metode deskriptif-analisis. Transformsi 
Jurnal Riset Agama, Volume 1, Nomor 3 (Desember 2021): 238-250

Tri Budi Prastyo, Risda Alfi Fat Hanna, Uun Yusufa, Hidayatul Fikra/Praktek Islam di Era Media Global: Konvergensi Media Sosial sebagai Sumber Ilmu Pengetahuan Agama Islam

pendidikan Islam diperlukan untuk membawa keluar dari krisis dan permasalahan. Penguatan lembaga pendidikan Islam juga perlu mendapatkan perhatian, seperti penguatan manajeman pendidikan Islam, penguatan kepemimpinan pendidikan Islam, dan reformasi kebijakan pendidikan, dengan dengan tujuan untuk membentuk generasi seutuhnya dan manusia unggul yang berdaya saing yaitu manusia kreatif, inovatif, berkarakter, mandiri, cinta tanah air dan religious untuk menghadapi Era 4.0 dimana manusia dituntut serba cepat, tepat, efektif dan efisien (Priyanto, 2020).

Penelitian terdahulu telah menyinggung problem pergeseran perilaku religiusitas masyarakat sebagai akibat konvergensi media massa mulai dari aspek kehidupan ekonomi, sosial, budaya dan politik (Sufyati, 2019). Beberapa temuan menarik dari penelitian ini mengungkap adanya ketergantungan siswa dalam penggunaan smartphone, di antaranya antusiasme siswa belajar agama dari para ustad pilihannya adalah media sosial (Hatta, 2018). Dalam praktek permasalahan transformasi pendidikan Islam sangat diperlukan untuk membawa keluar dari krisis dan permasalahan penguatan lembaga pendidikan Islam ini haruslah mendapatkan perhatian, meliputi penguatan manajeman pendidikan Islam, penguatan kepemimpinan pendidikan Islam, dan reformasi kebijakan pendidikan, dengan dengan tujuan untuk membentuk generasi seutuhnya dan manusia unggul.

Sebagai landasan teoritis penelitian ini maka dibutuhkan suatu tinjauan pustaka. Perkembangan dakwah dewasa ini harus sejalan dengan kemajuan ilmu pengetahuan, teknologi dan peradaban manusia supaya dakwah Islam mampu mewarnai ke seluruh aspek kehidupan manusia (Rahmawati., 2013). Praktek Islam di era global untuk konvergensi media sosial sebagai sumber ilmu pengetahuan agama Islam. Sebagaimana yang telah dijelaskan dalam paragraf pendahuluan, kemajuan teknologi telah menyebabkan perubahan sarana penyampaian informasi (Sufyati, 2019). Integrasi media konvensional ke dalam teknologi digital inilah yang kemudian dikenal dengan istilah konvergensi media sosial. Konvergensi merupakan pilihan yang harus dilakukan oleh media sosial, baik cetak maupun digital. Media massa harus mampu beradaptasi dengan perubahan teknologi, terutama dalam konteks industri media yang semakin kompetitif. Perkembangan teknologi ini berpengaruh pada gaya hidup masyarakat yang sering mencari informasi dengan membaca koran. Namun saat ini, banyak orang lebih memilih menggunakan internet untuk mencari berita, meskipun seseorang dapat secara langsung menjadi sumber informasi bagi orang lain. 
Jurnal Riset Agama, Volume 1, Nomor 3 (Desember 2021): 238-250

Tri Budi Prastyo, Risda Alfi Fat Hanna, Uun Yusufa, Hidayatul Fikra/Praktek

Islam di Era Media Global: Konvergensi Media Sosial sebagai Sumber Ilmu

Pengetahuan Agama Islam

\section{Metodologi Penelitian}

Metode penelitian ini menggunakan pendekatan kualitatif dengan studi kepustakaan (library research) yaitu menghimpun data dari tulisantulisan (literasi) yang mempunyai kaitan dengan topik yang dibahas, yaitu pendidikan Islam dalam era global ini. Data tersebut diambil dari referensi yang bentuk buku, jurnal penelitian, dan artikel-artikel yang mendukung. Metode pembahasan menggunakan metode deskriptif-analisis, yaitu menjelaskan serta mengelaborasi ide-ide utama yang berkenaan dengan topik yang dibahas. Kemudian menyajikannya secara kritis melalui sumber-sumber pustaka primer maupun skunder yang berkaitan dengan tema (Anggito \& Setiawan, 2018).

\section{Hasil Penelitian dan Pembahasan}

\section{Praktek Islam di Era Media Global}

Islam sebagai agama rahmatan lil 'alamin memiliki nilai-nilai dan tradisi berkomunikasi. Dalam perjalanan sejarahnya, nilai-nilai dan tradisi berkomunikasi yang telah dibangun pondasi-pondasinya pada zaman Rasulullah, mengalami pasang-surut sesuai dengan dinamika yang berkembang dalam perjalanan sejarah umat Islam. Dalam era global posisi dan peran Islam dalam komunikasi global belum menunjukkan peran yang signifikan. Hegemoni Barat masih begitu kuat dalam menguasai komunikasi global. Semua lini bisa dikatakan tidak terlepas dari intervensi Barat. Pada posisi demikian, Islam tidak harus berpangku tangan sambil merenungi nasibnya, melainkan perlu upaya-upaya yang sistematis agar dapat memainkan perannya di dalam komunikasi global.

Pada zaman Rasulullah berkembang tradisi tulis-menulis (Haramain, 2017). Terbukti ketika Rasulullah menerima wahyu langsung beliau memerintahkan para Sahabat yang memiliki kemampuan menulis untuk menulis wahyu yang diterima Baginda Rasulullah. Padahal saat itu, secara teknis sangat sulit untuk melakukan tulis-menulis apalagi mengetik disebabkan belum tersedianya sarana seperti kertas, alat tulis pena, dan belum ada internet seperti sekarang ini. Di samping budaya yang kurang mendukung, juga tidak ada akses semudah era global ini. Tetapi, Islam selama ini telah melakukan transformasi pada tataran paradigma, metode dan strategi pengembangan pendidikan Islam agar menjadi kekinian dan relevan dengan situasi dan kondisi global. Pendidikan Islam tetap dalam koridor cita-cita dan tujuan pendidikan yang bersandar pada Al-Qur'an dan Hadis serta berpijak pada tujuan pendidikan nasional, dasar negara dan filosofi. Berpegang pada prinsip al hifzu 'ala qodiimi as shoolih wa al akhzu 'ala jadiidi al aslah (mempertahankan tradisi yang baik dan mengadopsi kebaruan yang lebih baik) merupakan mantra paradigma berkemajuan, kontinuitas, keterbukaan dengan inovasi untuk melakukan transfer of 
Jurnal Riset Agama, Volume 1, Nomor 3 (Desember 2021): 238-250

Tri Budi Prastyo, Risda Alfi Fat Hanna, Uun Yusufa, Hidayatul Fikra/Praktek

Islam di Era Media Global: Konvergensi Media Sosial sebagai Sumber Ilmu

Pengetahuan Agama Islam

knowledge and technology yang maslahat bagi pengembangan pendidikan Islam (Priyanto, 2020). Religiusitas masyarakat sebagai akibat konvergensi media sosial tersebut, mulai dari aspek kehidupan ekonomi, sosial, budaya dan syariat beragama menghasilkan pergeseran media konvensional bahkan digital ke media sosial, hal ini memiliki dampak positif bagi yang memanfaatkan dengan positif, sebaliknya berdampak negatif jika memanfaatkannya dengan permainan saja.

Perkembangan teknologi kini sudah tidak bisa dihindari lagi, salah satunya adalah dengan adanya konvergensi media. Konvergensi media adalah penyatuan atau penggabungan berbagai media dan teknologi komunikasi (Asyir \& Nurbaya, 2019). Konvergensi media merupakan integrasi dari fungsi-fungsi beberapa media ke dalam satu media. Hal ini membuat runtuhnya tembok pemisah antara berbagai teknologi dan aplikasi komunikasi dan informasi, sehingga antara teknologi satu dan yang lainnya tidak dapat dibedakan lagi. Konvergensi muncul didorong oleh kebutuhan pengguna akan beberapa fungsi teknologi. Fungsi-fungsi tersebut awalnya berada pada media yang berbeda-beda, karena dorongan ini maka dihasilkanlah perpaduan dari beberapa fungsi ini ke dalam satu media saja. Berkembangnya suatu media sosial yang terus berkelajutan dan terus memperbarui isi konten sehingga menghasilkan konten yang beragam. Hal ini tentu tergantung bagaimana masyarakat bisa memanfaatkan teknologi yang berkembang dalam waktu yang terus berjalan sesuai kebutuhannya dan tidak merugikan diri sendiri serta orang lain. Tantangan-tantangan konvergensi media dalam kehidupan masyarakat tidak bisa dihindari karena mengikuti arah globalisasi. Hadirnya konvergensi media sosial sebagai sumber ilmu pengetahuan menjadi faktor penyebab perubahan pola interaksi masyarakat, khususnya dari segi sosialisasi yang memiliki pengaruh yang sangat berpengaruh besar. Bisa jadi karena kecanduan yang telah mendarah daging sehingga sulit untuk disembuhkan akibat ketergantungan akan media sosial itu sendiri.

Kompleksitas perkembangan, fenomena dan manifestasi kepercayaan dan agama kontemporer di Indonesia membuat tidak mungkin atau sangat sulit untuk dijelaskan secara relatif komprehensif (Gemiharto, 2015). Baik karena perkembangan pribadi maupun karena pengaruh bidang kehidupan lain. Agama mengalami perubahan yang cepat dalam berbagai aspek. Misalnya, keberadaan media sosial akibat konvergensi media mendorong masyarakat untuk terlibat dalam perilaku konsumsi. Namun, pertumbuhan media digital dapat berdampak positif pada peningkatan produktivitas di dunia industri. Kemajuan teknologi akan meningkatkan produktivitas dunia industri, baik dari segi teknologi industri maupun dari segi jenis produksinya. Pertumbuhan ekonomi akan lebih tinggi. Persaingan di dunia kerja memaksa pekerja untuk terus meningkatkan 
Jurnal Riset Agama, Volume 1, Nomor 3 (Desember 2021): 238-250

Tri Budi Prastyo, Risda Alfi Fat Hanna, Uun Yusufa, Hidayatul Fikra/Praktek Islam di Era Media Global: Konvergensi Media Sosial sebagai Sumber Ilmu Pengetahuan Agama Islam

keterampilan dan pengetahuannya. Pemanfaatan Teknologi Informasi dan Komunikasi (TIK) yang lebih luas akan membuka lebih banyak lapangan pekerjaan. Bersama dengan kemampuan untuk beriklan di Internet pada halaman tertentu, ini akan memudahkan untuk mempromosikan dan memasarkan produk. Bisnis dapat mengakses pasar yang lebih besar, karena pembeli memiliki akses ke Internet yang tidak dibatasi oleh lokasi dan waktu.

\section{Konvergensi Media Sosial sebagai Sumber Pengetahuan Agama}

Interaksi sosial sangat jarang terjadi karena adanya konvergensi media. Masyarakat kehilangan kesempatan untuk berkomunikasi secara langsung padahal dalam praktik mencari ilmu agama tidaklah sembarangan untuk mengambil riwayat tanpa kejelasan sanad. Secara perlahan fenomena ini telah membawa masyarakat ke dalam sebuah budaya yang cenderung ketergantungan terhadap teknologi.

Memang kemajuan teknologi komunikasi yang cepat dapat mempermudah komunikasi antar manusia dari suatu tempat ke tempat yang lain. Sosialisasi kebijakan pemerintah dapat lebih cepat disampaikan kepada masyarakat banyak. Informasi yang ada di masyarakat dapat langsung dipublikasikan dan diterima oleh masyarakat lainnya(Chandra, 2020). Namun, sisi negatifnya dengan makin pesatnya komunikasi membuat bentuk komunikasi berubah, yang asalnya face to face menjadi sebatas via online. Hal ini dapat menyebabkan komunikasi yang buruk dalam praktek ini. Kemajuan kehidupan ekonomi yang terlalu menekankan pada upaya pemenuhan berbagai keinginan material, telah menyebabkan sebagian warga masyarakat menjadi kaya dalam materi tetapi miskin dalam rohani. Pada hal seperti di atas, jika dikontekstualisasikan dengan perubahan perilaku beragama di Indonesia saat ini, ada hubungan yang signifikan antara agama dan media. Pertumbuhan media juga menambah keunikan hubungan antara agama dan media. Pada tahap perkembangan ini, tampaknya media akan menjadi agama bagi sebagian orang. Media tidak hanya berperan sebagai produsen budaya, tetapi juga sebagai agama atau teologi bagi sebagian orang. Agama dan media memiliki hubungan timbal balik sangat besar dan saling mempengaruhi. 
Jurnal Riset Agama, Volume 1, Nomor 3 (Desember 2021): 238-250

Tri Budi Prastyo, Risda Alfi Fat Hanna, Uun Yusufa, Hidayatul Fikra/Praktek Islam di Era Media Global: Konvergensi Media Sosial sebagai Sumber Ilmu Pengetahuan Agama Islam

Gambar 1. Konten Dakwah dalam Media Sosial Youtube

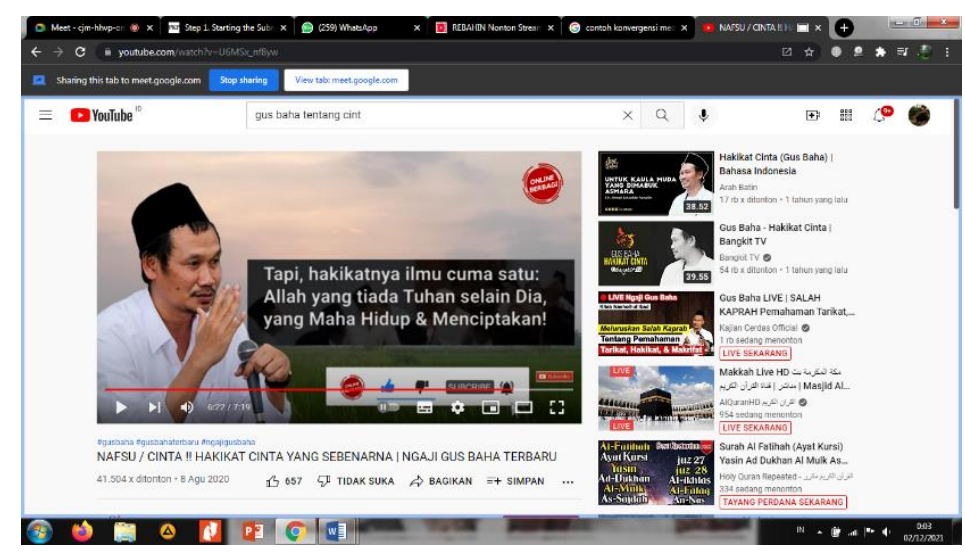

Seperti contoh konten dakwah yang sering ditayangkan di salah satu media sosial youtube mengenai hakikat cinta misalnya, banyak hal bisa diakses dengan mudah dengan cara mengetik keyword di dalam pencarian yang telah disediakan setiap media sosial untuk mencari konten-konten dakwah sebagai sumber pengetahuan agama. Dalam gambar 1, pembahasan dalam isi ceramah yang telah disampaikan oleh salah satu tokoh agama yang masyhur di era milenial ini menjelaskan hakikat cinta yang sesungguhnya. Gus Baha menyampaikan hakikat dari cinta adalah tentang penyatuan antara rasa yang ada diselaraskan hanya kepada Sang Pencipta, hakikatnya itu hanya satu dikembalikan semua kepada Allah yang tiada Tuhan selain Dia Sang Maha Cinta.

Pandangan Soerjono Soekanto setidaknya bisa dilihat di berbagai aktivisme masyarakat muslim di media massa, termasuk sosial media. Masyarakat muslim (netizen-red) seringkali menjadikan media massa tertentu termasuk sosial media sebagai acuan dalam beragama. Berbagai konten keagamaan yang diposting di media tertentu dianggap sebagai kebenaran mutlak yang tidak membuka ruang untuk dialog. Kondisi ini seringkali menyebabkan sebagian masyarakat muslim memahami ajaran agama secara kaku (Soekanto, 2014). Pemahaman keagamaan yang kaku akan berpotensi menyebabkan konflik sosial karena meningkatnya sense keagamaan pada diri mereka. Meski demikian, keberadaan media dengan muatan agama juga memiliki sisi positif. Di antaranya adalah meningkatnya minat masyarakat pada isu-isu agama. Hal ini disebabkan oleh kemudahan masyarakat muslim untuk mengakses materi dan isu keagamaan, baik melalui internet, sosial media, maupun media massa yang lain. Sebagai contoh menjamurnya komunitas hijrah di kalangan artis, komunitas hijabers, hingga bermunculannya kelas sosialita baru yang menampilkan hedonitas dalam bingkai agama bukan hanya itu banyak komunitas pemuda gaul untuk mengajak kembali menebar kebaikan dan saling peduli kebaikan. 
Jurnal Riset Agama, Volume 1, Nomor 3 (Desember 2021): 238-250

Tri Budi Prastyo, Risda Alfi Fat Hanna, Uun Yusufa, Hidayatul Fikra/Praktek Islam di Era Media Global: Konvergensi Media Sosial sebagai Sumber Ilmu Pengetahuan Agama Islam

Gambar 2. Konten Dakwah dalam Media Sosial Instragram
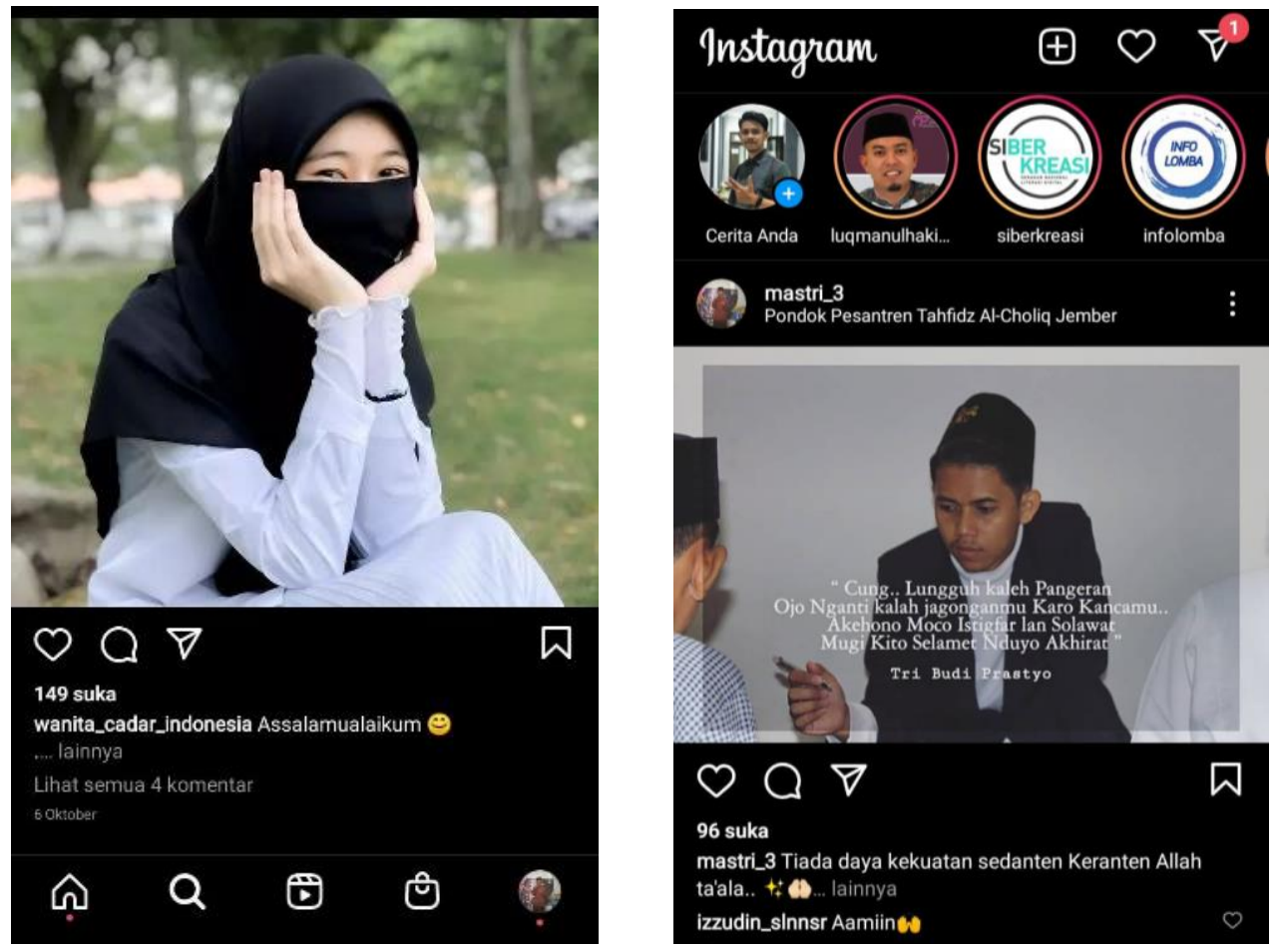

Dalam gambar 2, menunjukkan bahwa konten isu-isu maraknya komunitas hijrah dengan ditandainya hijabers di kalangan wanita. Untuk kalangan lain tidak dipastikan juga mencari konten nasehat kehidupan seperti contoh gambar di atas, isi dari kontennya adalah menasehati seluruh pengguna media sosial Instragram khususnya, yaitu "dalam kehidupan ini jangan sampai kita duduk bersama teman, saudara, atau sahabat lebih lama daripada duduk dan bersujud menghadap Yang Maha Kuasa. "Di sana dijelaskan dalam bahasa jawa "Cungg.. Lungguh kaleh Pangeran ojo nganti kalah jagonganmu karo kancamu. Akehono moco Istighfar lan Solawat mugi kito selamet dunyo akhirat." Dari sini bisa dilihat bahwa media sosial ketika dijadikan sumber pengetahuan agama ini sangat mudah pengaksesannya melalui konten-konten yang ada di Instagram. Oleh karena itu, perubahan masyarakat digital yang dalam langkah ke depan akan membawa pada perubahan perilaku dan pemikiran keagamaan di masyarakat. Ketika tidak ada aspek lain yang mengontrol penyebaran pengetahuan, kesadaran akan isu-isu keagamaan di media sosial yang akan menjadi isu tersendiri bagi masyarakat. Media massa sebagai penyedia layanan informasi dan sebagai sumber ilmu pengetahuan agama, pada akhirnya dituntut untuk dapat menjalankan fungsinya sebagai bagian dari platform globalisasi. Sehingga, keberadaannya tidak menjadi pemicu kepekaan terhadap perbedaan demi keuntungan ekonomi, tetapi 
Jurnal Riset Agama, Volume 1, Nomor 3 (Desember 2021): 238-250

Tri Budi Prastyo, Risda Alfi Fat Hanna, Uun Yusufa, Hidayatul Fikra/Praktek Islam di Era Media Global: Konvergensi Media Sosial sebagai Sumber Ilmu Pengetahuan Agama Islam

setidaknya mampu menjalankan fungsi layanan yang mandiri, tunduk pada tanggung jawab profesional atas isi informasi kepada publik dan memastikan keragaman budaya dan sosial. Meskipun globalisasi telah membawa perubahan besar di lingkungan masyarakat yang mengakibatkan perubahan besar dalam penerapan teknologi di bidang pendidikan seperti pendidikan Islam khususnya, namun telah berdampak pada kualitas operasi dan sumber daya masyarakat yang meningkat. Karena seseorang dituntut memiliki keberanian untuk keluar dari zona nyaman dengan perubahan metode pembelajaran baru dan dengan memasukkan pendidikan Islam ke dalam pedoman hidup generasi milenial tanpa merendahkannya (Siti et al., 2021).

\section{Kesimpulan}

Islam di masa era global dengan praktek dakwah dunia digital yang berkembang dengan cepat dapat mengimbangi globalisasi dalam kehidupan sehari-hari untuk digunakan dalam komunikasi dan memberikan informasi. Hal ini dikarenakan dalam penyampaiannya terlihat modern tanpa mengurangi nilai agama tersebut dan media yang digunakan juga sangat efektif. Dari sini dapat kita lihat penggunaan teknologi dengan baik dalam pendidikan agama Islam banyak membawa positif bagi kaum milenial.

Dalam konteks keagamaan, konvergensi media sosial sebagai sumber ilmu pengetahuan ini menimbulkan dampak positif dan negatif. Meningkatnya minat keagamaan pada masyarakat muslim dan kemudahan akses untuk mendapatkan materi dan isu keagamaan menjadi penanda positif, namun hal tersebut bisa berpotensi mempertajam sensitivitas perbedaan di masyarakat. Berdasarkan hasil analisis isi, terlihat bahwa kebijakan media sosial memberikan dampak pada proporsi dan intensitas pemberitaan oleh media sosial. Hal ini menunjukkan bahwa objektivitas media dipengaruhi oleh kebijakan media.

Sesuai dengan kesimpulan di atas, maka penulis memberikan beberapa saran-saran yakni: 1) Media sebagai alat penyampaian pesan haruslah selalu menjaga agar berita selalu sesuai dengan fakta dalam menyampaikan pemberitaan terutama dalam kajian kajian ilmu; dan 2) Masyarakat harus lebih jeli dalam memaknai setiap informasi yang terkandung di dalam sebuah konten. Karena bisa saja informasi tersebut merupakan hasil konstruksi dari wartawan bahkan pendakwah tidak sesuai dengan realitas yang sebenarnya. Pengaruh yang diterima media kadang membuat pergeseran makna yang mestinya disadari dengan baik oleh masyarakat.

Hasil penelitian ini diharapkan memberikan implikasi manfaat, baik teoritis maupun praktis. Secara teoritis, penelitian ini diharapkan dapat memberikan sumbangan untuk pengayaan khazanah pengetahuan Islam. 
Jurnal Riset Agama, Volume 1, Nomor 3 (Desember 2021): 238-250

Tri Budi Prastyo, Risda Alfi Fat Hanna, Uun Yusufa, Hidayatul Fikra/Praktek Islam di Era Media Global: Konvergensi Media Sosial sebagai Sumber Ilmu Pengetahuan Agama Islam

Secara praktis, penelitian ini diharapkan menjadi rujukan dalam penerapan Konvergensi media sosial sebagai sumber ilmu pengetahuan agama Islam. Penelitian ini memiliki keterbatasan dalam menyajikan analisis sehingga diperlukan penelitian lebih lanjut dengan menerapkan pendekatan yang lebih tajam dan relevan. Penelitian ini merekomendasikan kepada institusi pendidikan agama Islam untuk meninjau media sebagai konvergensi pengetahuan Islam.

\section{Daftar Pustaka}

Anggito, A., \& Setiawan, J. (2018). Metodologi Penelitian Kualitatif. CV Jejak. Asyir, A. K., \& Nurbaya, S. (2019). Konvergensi Media dan Mediamorfosis:

Strategi Digitalisasi Majalah Moeslim Choice dalam Proses Transformasi Basis Kerja. Jurnal Studi Jurnalistik, 1(1), 52-67.

Azmi, K. R. (2019). Model Dakwah Milenial Untuk Homoseksual Melalui Teknik Kontinum Konseling Berbasis Alquran. Al-Balagh: Jurnal Dakwah Dan Komunikasi, 4(1), 25.

https:/ / doi.org/10.22515/balagh.v4i1.1557

Chandra, P. (2020). Problematika, Tantangan dan Peluang Pendidikan Agama Islam di Sekolah dan Perguruan Tinggi di Era Globalisasi. Jurnal Aghinya Stiesnu Bengkulu, 3(1), 124-136.

Fatoni, U., \& Nafisah Rais, A. (2018). Pengelolaan Kesan Da'i dalam Kegiatan Dakwah Pemuda Hijrah Uwes Fatoni Annisa Nafisah Rais. Komunika: Jurnal Dakwah Dan Komunikasi, 12(2), 211-222.

Gemiharto, I. (2015). Teknologi 4G-Lte Dan Tantangan Konvergensi Media Di Indonesia. Jurnal Kajian Komunikasi, 3(2), 212-220.

https:/ / doi.org/10.24198/jkk.vol3n2.10

Haramain, M. (2017). Dakwah dalam Arus Globalisasi Media: Peluang dan Tantangan. Komunida: Media Komunikasi Dan Dakwah, 7(1), 60-73. https://doi.org/10.35905/komunida.v7i1.471

Hatta, M. (2018). Media Sosial sebagai Sumber keberagamaan Alternatif Remaja dalam Fenomena Cyberreligion. Jurnal Kajian Dakwah Dan Kemasyarakatan, 22(1), 1-30.

Priyanto, A. (2020). Pendidikan Islam dalam Era Revolusi Industri 4.0. JPAI: Jurnal Pendidikan Agama Islam, 6(2), 80-89.

https://doi.org/10.18860/jpai.v6i2.9072

Rahman, A., \& Nuryana, Z. (2020). Pendidikan Islam di Era Revolusi Industri 4.0. J-PAI: Jurnal Pendidikan Agama Islam, 6(2), 80-89.

Rahmawati., I. (2013). Potret Dakwah di Tengah Era Globalisasi dan Perkembangan Zaman. At-Tabsyir, 1(1), 191-199. https://doi.org/10.2307/j.ctt46nrzt.12

Siti, E., Aisyah, N., Hardini, M., Riadi, B., \& Islam, P. A. (2021). Peran Teknologi dalam Pendidikan Agama Islam pada Globalisasi untuk Kaum Milenial (Pelajar). 1(1), 65-74. 
Jurnal Riset Agama, Volume 1, Nomor 3 (Desember 2021): 238-250

Tri Budi Prastyo, Risda Alfi Fat Hanna, Uun Yusufa, Hidayatul Fikra/Praktek Islam di Era Media Global: Konvergensi Media Sosial sebagai Sumber Ilmu Pengetahuan Agama Islam

Soekanto, S. (2014). Sosiologi Suatu Pengantar. Jakarta : Rajawali Pers.

Sufyati. (2019). Konvergensi Media dalam Religiusitas Masyarakat. Sosiologi Reflektif, 13(2), 313-330. 